\title{
Individuals' Financial Satisfaction and National Priority: A Global Perspective
}

\author{
Hassan F. Gholipour ${ }^{1} \cdot$ Reza Tajaddini $^{2} \cdot$ Farhad Taghizadeh-hesary $^{3}$
}

Accepted: 19 September 2021 / Published online: 24 September 2021

(c) The Author(s), under exclusive licence to Springer Nature B.V. 2021

\begin{abstract}
The purpose of this study is to examine the association between financial satisfaction and individuals' preferences for various national priorities (including economic growth, national defense, freedom of speech, and having a beautiful nation). Using the sixth wave of World Value Survey (2010-2014) data for 60 countries, our Probit regression analyses show a positive and significant relationship between individuals' financial satisfaction and individuals' preferences for freedom of speech and having a beautiful nation. We also find that financial satisfaction is negatively associated with the priority of economic growth but not statistically related to the priority of national defense. These findings are robust when we use a Probit model with endogenous regressors and country-level data with a 2SLS estimator. The regression results also show that the preference for a stronger national defense is higher among individuals who are older, married, nationalistic, educated and have jobs in the public sector. Finally, we find that people with lower education and income and those with full-time employment and non-government jobs are more interested in the economic growth of their countries.
\end{abstract}

Keywords Financial satisfaction · National priority $\cdot$ Economic growth $\cdot$ Freedom of speech · Preference

JEL Classification C21 $\cdot \mathrm{D} 71 \cdot \mathrm{D} 72 \cdot \mathrm{D} 91$

Hassan F. Gholipour

H.Fereidouni@westernsydney.edu.au

Reza Tajaddini

rtajaddini@swin.edu.au

Farhad Taghizadeh-hesary

farhad@tsc.u-tokai.ac.jp

1 School of Business, Western Sydney University, Sydney, Australia

2 School of Business, Law, and Entrepreneurship, Swinburne University of Technology, Melbourne, Australia

3 Social Science Research Institute, Tokai University, Tokyo, Japan 


\section{Introduction}

For a long time, developing policies and designing services that accommodate public opinions have been major concerns of normative democratic theory (Sen, 2018), economists (Davis et al., 1970), and policymakers (Page \& Shapiro, 1983) in democratic countries. The failure of elected officials to implement policies that reflect people's will may lead to principal-agent problems (Tomz et al., 2020). As such, understanding factors that explain public preference is imperative.

In this paper, we explore whether individuals' financial satisfaction is related to their preferences for the future direction of their countries. Financial satisfaction is the selfassessment of satisfaction with personal financial domains such as income level, savings, and the ability to service liabilities and unpredicted financial burdens (Gerrans et al., 2014; Prawitz et al., 2006). The determinants of financial satisfaction have been debated at length (Brown et al., 2014; Fan \& Babiarz, 2019; Plagnol, 2011; Tharp et al., 2020; West \& Cull, 2020; Xiao et al., 2014). Some researchers (Archuleta et al., 2011; Boyle, 2012; Chong et al., 2014; Grable et al., 2007; Rautio et al., 2012; Stack \& Cao, 1997) have also examined the association between financial satisfaction and socioeconomic variables (e.g., female suicide attitudes, thoughts of subsequent divorce, marital satisfaction, marital instability, bequest motives, life satisfaction and quality of life).

However, to the best of our knowledge, satisfaction with one's financial situation has not been used as an independent variable in an empirical setting to explain the preference for national political preferences. We address this gap by investigating the relationship between financial satisfaction and the national priorities, which are detailed in the sixth round of the World Values Survey (WVS6, covering 2010-2014) (Inglehart et al., 2014). They include economic growth, national defense, freedom of speech, and having a beautiful nation. The WVS6 survey was collected from more than 85,000 individuals in 60 countries and societies. This large sample size provides a standardized procedure and instrument that allow international comparisons with a great statistical power for analyses.

Our study is inspired by Maslow's $(1943,1954)$ theory of hierarchy of needs, Inglehart's $(1971,1997)$ theory of value change, and the revised theory of modernization that is presented in Inglehart and Welzel's (2005).

Based on Maslow's theory of hierarchy of needs, people are driven to address certain desires before fulfilling the next one. The original hierarchy of needs included biological and physiological, safety, social, esteem, and self-actualization needs. Later, Maslow (1970) added cognitive, aesthetic, and transcendence needs to the model. Based on this theory, as individuals satisfy their basic needs such as food and shelter (biological) and protection from enemy (safety), they move on to fulfill their more advanced needs, such as searching for beauty (aesthetic) and practicing democratic attitudes (self-actualization).

A similar transition from materialist to postmaterialist values at a societal/national level is discussed in the theory of value change. The theory applies the scarcity hypothesis and argues that people in societies with weak economic conditions place more importance on survival and materialist needs. Inglehart $(1971,1997)$ suggests that individuals' priorities reflect their socioeconomic environment, and as societies progress with economic development and address material concerns, people shift their attention to postmaterialist values such as self-expression values, quality of life, and free choice. Moreover, the revised theory of modernization suggests that economic development and modernization trigger cultural changes that lead to individual autonomy, gender equality, and democracy (Inglehart \& Welzel, 2005). 
Relying on the above discussions, we postulate that individuals at higher levels of financial satisfaction tend to give higher preference to postmaterialist national priorities of freedom of speech and a beautiful nation than the materialist priorities of economic growth and national defense. The justification is that as individuals progress with their financial accomplishments, they feel more confident in their financial status and, therefore, climb Maslow's hierarchy of needs and fulfill their potential. Satisfaction with materialistic achievements may lead to the shift of attention from materialist to postmaterialist values. This means practicing aesthetic and self-actualization needs are more appreciated by financially satisfied people.

Nevertheless, it is possible to find the counter-arguments of this claim in the literature. For example, Beamer (2010) and Farzanegan and Gholipour (2021) present evidence that higher income groups of society may prefer a stronger order, security, and national defense forces as they have higher economic interests that require protection. In other words, the costs of not having a strong defense would be felt more significantly by high-income earners (Beamer, 2010, pp. 22-23). Ng and Diener (2014) argue that money to secure material goods and comforts is more crucial in developed nations than the underdeveloped agricultural societies, where basic materialistic needs can be obtained through alternative means. The authors find that citizens of affluent countries are more concerned about material well-being and economic development to ensure the continuation of their comfortable lifestyles. As such, wealthier individuals may prefer more robust economic growth and national defense forces as they have higher economic interests that may be at risk if the economy slows down or political instability rises.

These contradictory views offer an interesting context to test the association between financial satisfaction and national priorities across countries.

Since we are dealing with a binary dependent variable, we adopt a static Probit model as the estimation method. To ensure our results are not suffering from an endogeneity problem, we also use a Probit model with endogenous regressors. Our results show that advances in financial satisfaction lead people to seek fulfillment of their postmaterialist values. Further to individual-level analysis, we also conduct a country-level analysis applying Ordinary Least Squares (OLS) and Two-Stage Least Squares (2SLS) methods. The results of these analyses also, in general, confirm our main findings.

This paper contributes to the existing literature by expanding our understanding of the relations between financial satisfaction and political and national preferences. Moreover, this study utilizes three psychological theories-hierarchy of needs, value change, and modernization - to explain how the sense of financial satisfaction can change individuals' perceptions toward materialist and postmaterialist values.

This study proceeds as follows: Sect. 2 describes the data and methodology, Sect. 3 presents the regression results, and Sect. 4 concludes the study. 


\section{Data and Methodology}

Data for all variables of this study were obtained from the sixth wave of WVS covering 2010-2014 ${ }^{1}$ (Inglehart et al., 2014). The survey was collected from more than 85,000 respondents in 60 countries and societies in one of the years between 2010 and 2014. For example, the survey was conducted in Australia in 2012 but for Germany in 2013. Therefore, our data set is cross-sectional but not longitudinal. It is noteworthy that the WVS data have been widely accepted and used by several political and economic researchers over the past four decades (e.g., Facchini \& Melki, 2019; Maseland \& Hoorn, 2011).

\subsection{Dependent Variable}

Among the various belief and preference questions, the WVS survey contains a set of questions regarding individuals' views about what their home country's aims should be for the next ten years. The question asks the respondents, "People sometimes talk about what the aims of this country should be for the next ten years. On this card are listed some of the goals which different people would give top priority. Would you please say which one of these you, yourself, consider the most important? (Code one answer only under "first choice")":

- A high level of economic growth.

- Making sure this country has strong defense forces.

- Seeing that people have more say about how things are done at their jobs and in their communities.

- Trying to make our cities and countryside more beautiful.

The true intention of the fourth priority, we believe, is most likely to consider having an environmentally sustainable nation. For our analysis, we have recoded the responses by a dummy variable which equals 1 if the respondents mention one of the goals as their first choice and 0 if otherwise. Table 1 shows what percentage of total respondents in WVS wave six selected as the first choice for various national aims. Most respondents chose economic growth as the first choice $(60.2 \%)$, followed by freedom of speech $(17.3 \%)$, national defense (13.4\%), and beautiful nation $(6.9 \%)$.

\subsection{Explanatory Variable of Interest}

Our main explanatory variable of interest is the logarithm of financial satisfaction. WVS asks the following question in their survey: "How satisfied are you with the financial situation of your household?" (code one number): (1 Completely dissatisfied-10 Completely satisfied). The mean and standard deviation for financial satisfaction (before taking the logarithm) are 5.86 and 2.49 .

\footnotetext{
1 The complete dataset for WVS6 are available at http://www.worldvaluessurvey.org/WVSDocumentatio nWV6.jsp. We do not use WVS7 because the survey was conducted in several countries in 2019 and 2020; years affected by the COVID-19 pandemic. This interruption in the world during this unusual period can significantly alter respondents' opinions about countries' aims.
} 
Table 1 Aims of country: first choice

\begin{tabular}{lllllll}
\hline & $\begin{array}{l}\text { Economic } \\
\text { growth }\end{array}$ & $\begin{array}{l}\text { National } \\
\text { defense }\end{array}$ & $\begin{array}{l}\text { Freedom of } \\
\text { speech }\end{array}$ & $\begin{array}{l}\text { Beautiful } \\
\text { nation }\end{array}$ & No answer & $\begin{array}{l}\text { Don't } \\
\text { know }\end{array}$ \\
\hline $\begin{array}{c}\% \text { of total } \\
\text { respondents }\end{array}$ & $60.2 \%$ & $13.4 \%$ & $17.3 \%$ & $6.9 \%$ & $1 \%$ & $1.2 \%$ \\
\hline
\end{tabular}

Source: WVS wave 6

\subsection{Control Variables}

To model the relationship between financial satisfaction and national priorities, it is important to control for other possible socio-demographics of respondents, which may shape the perception of individuals regarding their first choice for the aim of their country. Similar to other empirical studies about the determinants of individual's preferences (e.g., Alesina \& Fuchs-Schündeln, 2007; Giuliano \& Spilimbergo, 2014), we are limited to the explanatory variables that are available in the survey. Nevertheless, regardless of which control variables are included in the model, the sign and significance of coefficients for financial satisfaction do not change (e.g., see columns 1 to 8 of Table 3 ).

In our estimations, we control for marital status, gender, employment status, education, town size, religiosity, willingness to fight for country, type of job, age, income (scaled 1 to 10), and confidence in government (in a Likert scale ranging from 1 (none at all) to 4 (a great deal of confidence)). Table 2 shows the list of all variables that might influence the national priority of individuals. We control for these factors by introducing dummy variables for most of them.

\subsection{Estimation Method}

Since the dependent variable is a binary variable that takes on values of 0 and 1 , we apply a static $^{2}$ Probit regression for our estimation, which assumes that the probability of a positive outcome is determined by the standard normal cumulative distribution function. In other words, we interpret a value of zero as a negative outcome (failure) and treat a value of one as a positive outcome (success).

The static Probit model is specified as follows:

$$
\operatorname{Pr} \operatorname{ob}\left(\text { PRIORITY }_{j} \neq 0 \mid x_{j}\right)=\Phi\left(x_{j} \beta\right)
$$

where PRIORITY $\mathrm{j}_{\mathrm{j}}$ indicates that the response to one of the questions is related to the

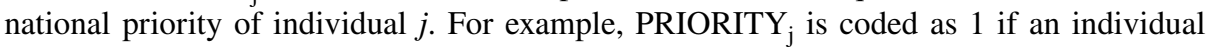
mentioned "economic growth" as the first choice of the country's aims and 0 if otherwise. We code other priorities using the same approach. $\Phi$ is the standard cumulative normal, $\mathrm{x}_{\mathrm{j}}$ represents the explanatory variables, and $\boldsymbol{\beta}$ is a vector of parameters to be estimated.

We used robust standard errors in our estimations. This option specifies that the standard errors, which are the square root of the variances of the variance-covariance matrix,

\footnotetext{
${ }^{2}$ We do not apply dynamic Probit model because our data is not longitudinal as we do not observe an individual over time.
} 


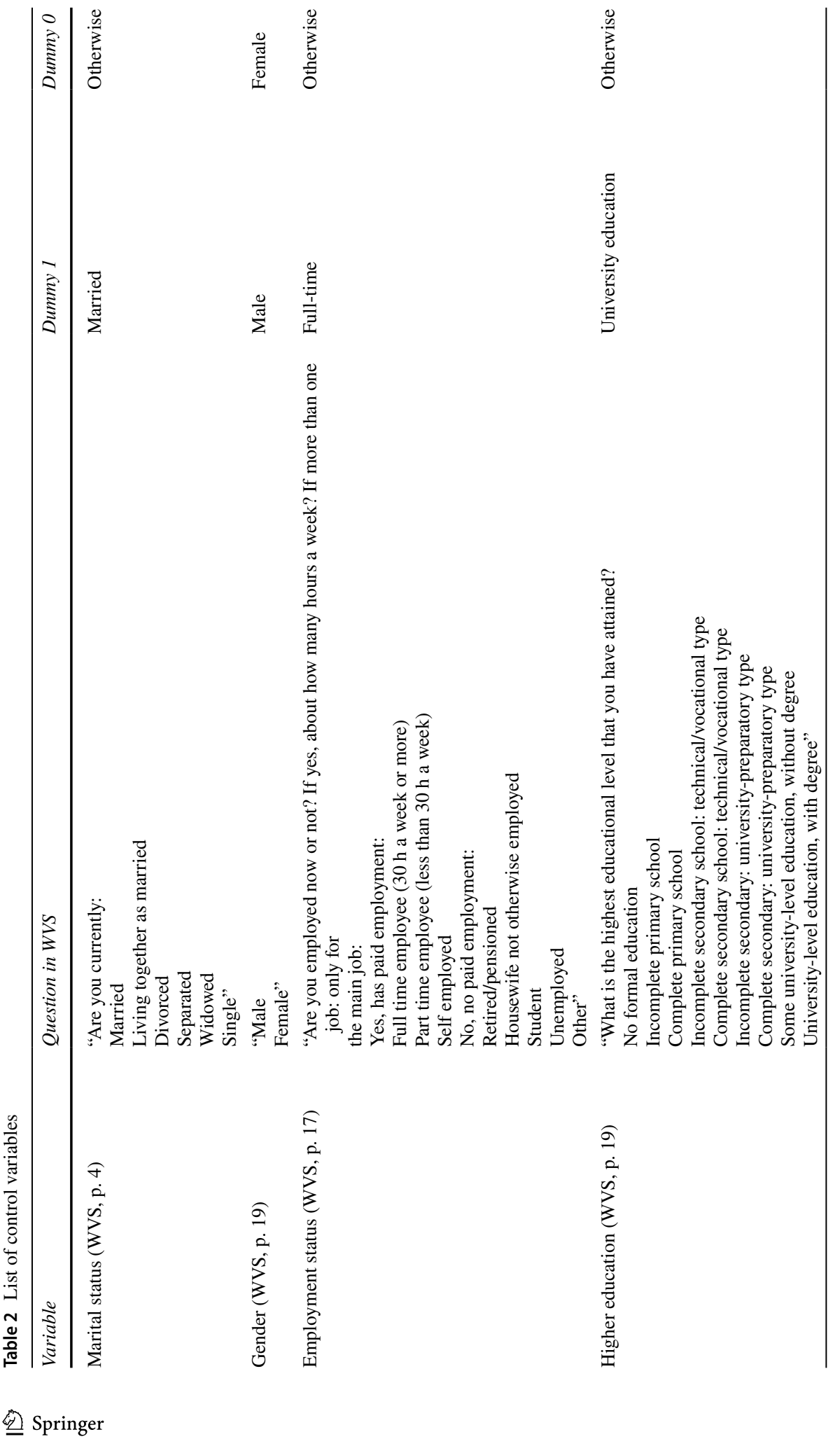




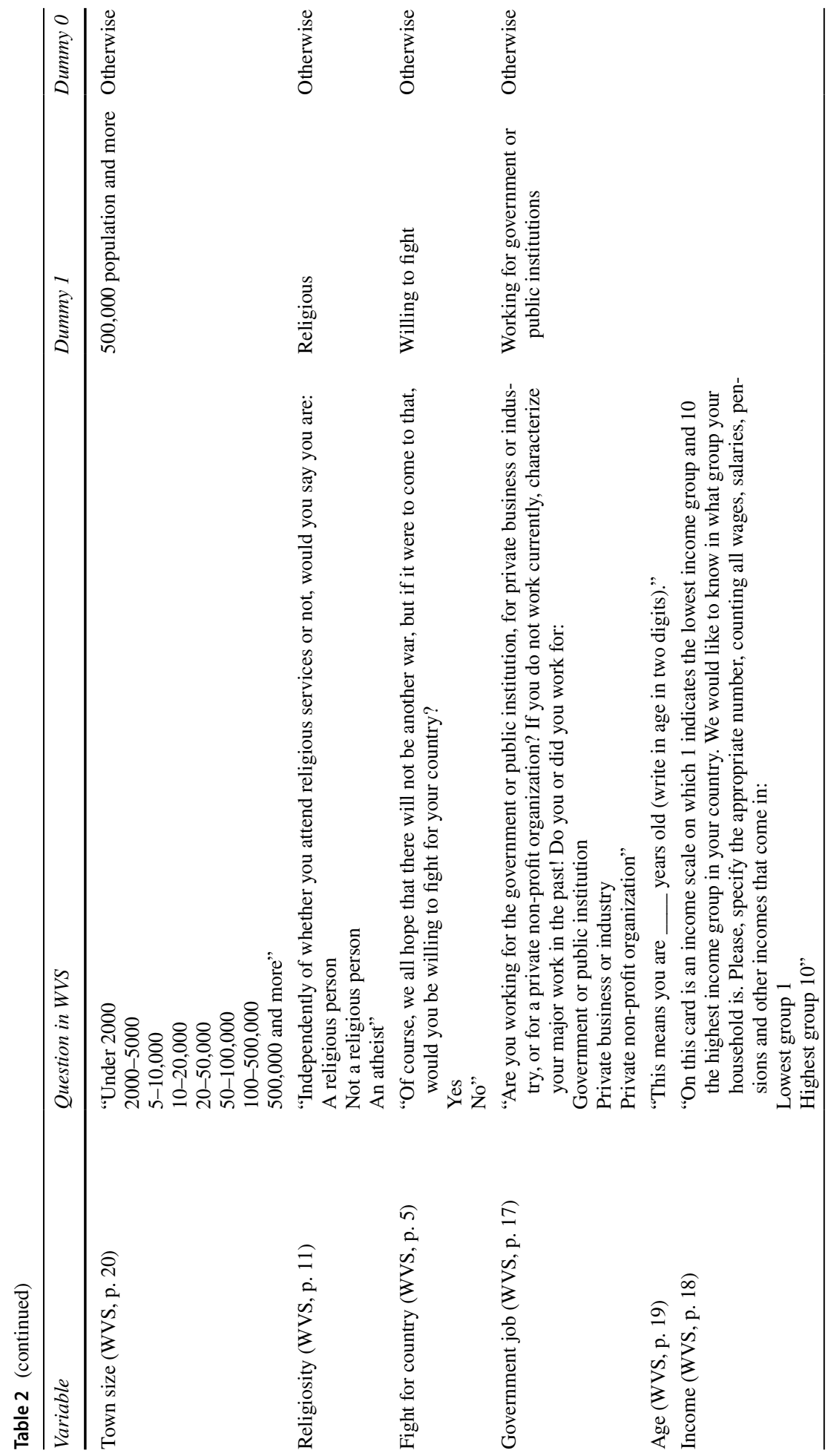




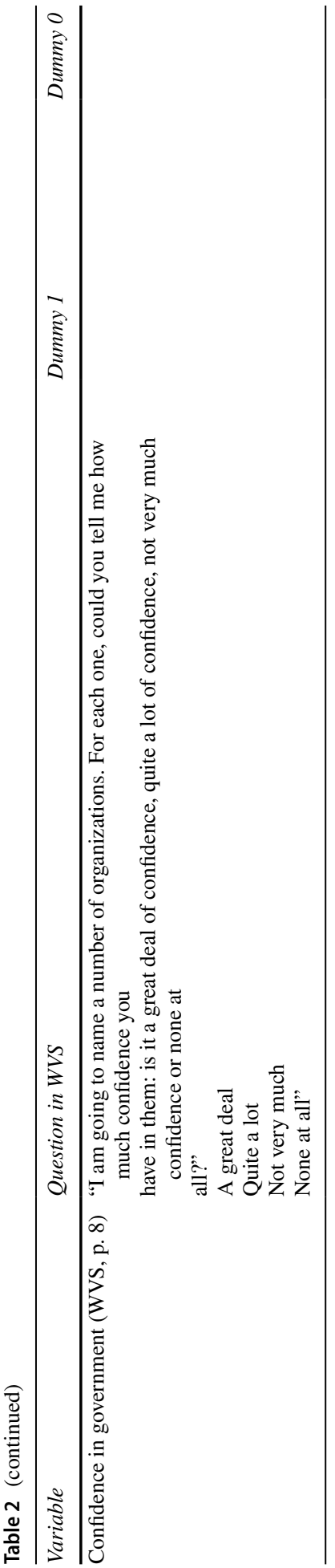


are based on the robust variance estimator. It means our estimates are not prone to the heteroskedasticity issue in the residual distribution.

The Probit model is a common estimation method in studies that use WVS data, and the dependent variables take values of 0 and 1 (e.g., Facchini \& Melki, 2019; Heinemann, 2008). Finally, all analyses are conducted by the statistical software package StataSE 16.

\section{Results}

Table 3 presents the results of the Probit regressions. In columns 1, 3, 5, and 7 of Table 3, financial satisfaction is only included as an explanatory variable for various national priorities. In columns $2,4,6$, and 8 , we insert control variables in the models. The results indicate that individuals with higher levels of financial satisfaction have a tendency towards freedom of speech and having a beautiful nation. The coefficient of financial satisfaction is positive and significant when we use freedom of speech and beautiful nation as dependent variables (see columns 6 and 8). We also find that financial satisfaction is negatively associated with the priority of economic growth (columns 1 and 2 of Table 3). Finally, the analyses suggest that there is an insignificant link between financial satisfaction and the priority of national defense (columns 3 and 4 of Table 3).

In general, these results are aligned with Maslow's (1943, 1954) theory of hierarchy of needs, Inglehart's $(1971,1997)$ theory of value change, and the revised theory of modernization. It is possible to infer from these results that as individuals achieve higher satisfaction with their financial situation, they shift their attention to fulfilling more advanced goals in life. This justifies their tendency to support progressive national objectives such as freedom of speech and a beautiful living environment aligned with the self-actualization and aesthetic needs in Malsow's hierarchy pyramid, respectively.

Theory of value change and revised theory of modernization also argue that economic security enables a value transition from the fulfillment of material concerns to postmaterialist needs. In other words, economic factors tend to play a pivotal role under conditions of economic scarcity, but their marginal utility is diminished as countries progress with technological and economic development (Inglehart \& Flanagan, 1987). Instead, as people prioritize values around self-expression, self-actualization, and the quality of life, postmaterialist values start to play a more decisive role in shaping societies. This can lead to the rise of new social and environmentalist movements (Bennulf \& Holmberg, 1990; Inglehart \& Abramson, 1994). Spaiser et al. (2014) also show that as people reach a certain standard of living and financial security that relieves them from daily existential worries, they start planning for long-term societal and environmental goals.

It has been shown that financial satisfaction has a vital influence on overall life satisfaction (Brown et al., 2014); in this study, however, we show that financial satisfaction can have boarder implications for the future direction and general well-being of nations. Although our results are based on a very large sample at the individual level, the results must be interpreted with caution.

We are not claiming that the postmaterialist needs that are investigated in this study (i.e., support for freedom of speech and a beautiful living environment) become important only after individuals attain a certain level of affluence. Of course, it is easy to find considerable evidence that people in weak financial conditions still admire postmaterialist values. However, we suggest that there is, on average, a gradual tendency toward a greater appreciation of the postmaterialist national priorities as individuals obtain higher levels of 


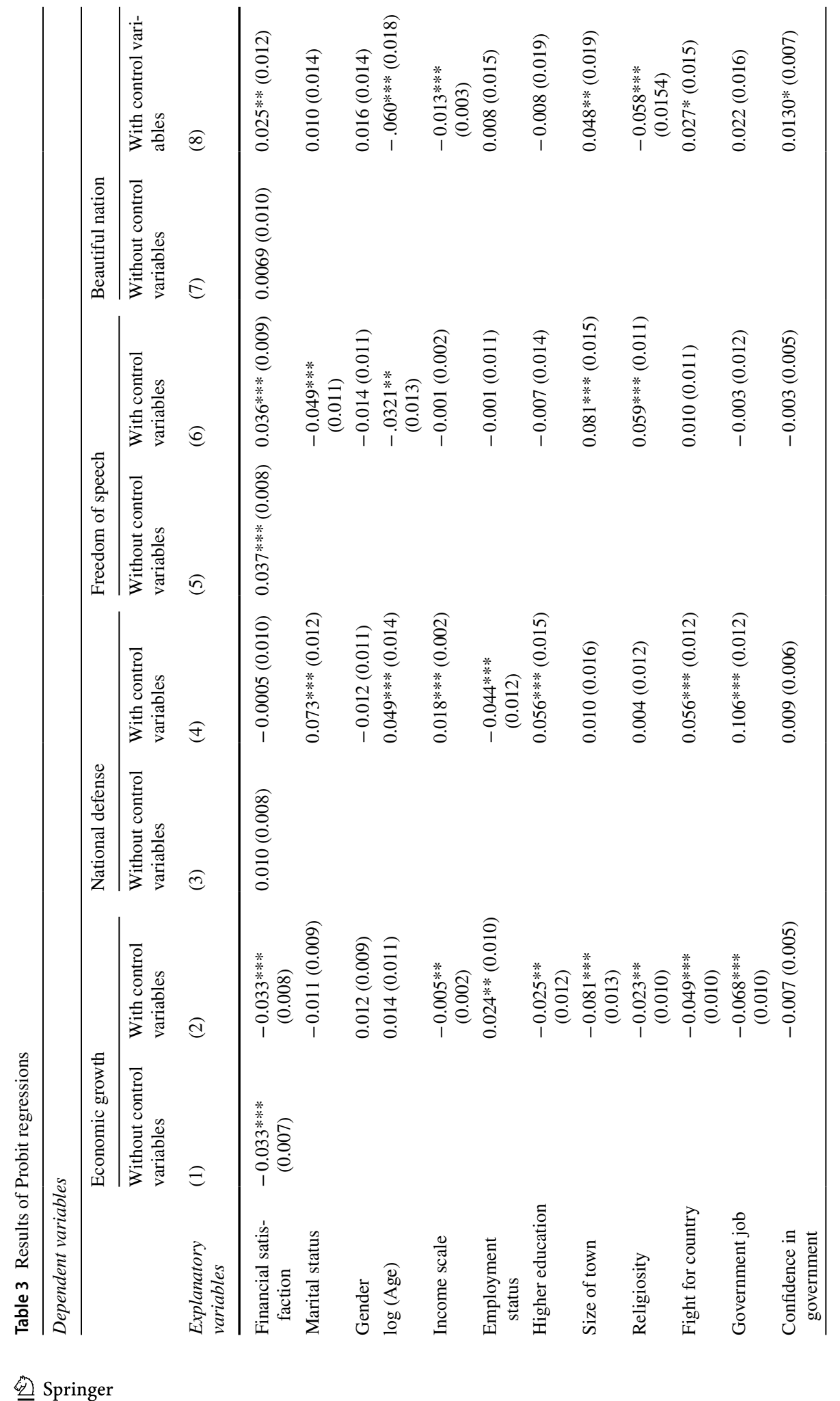




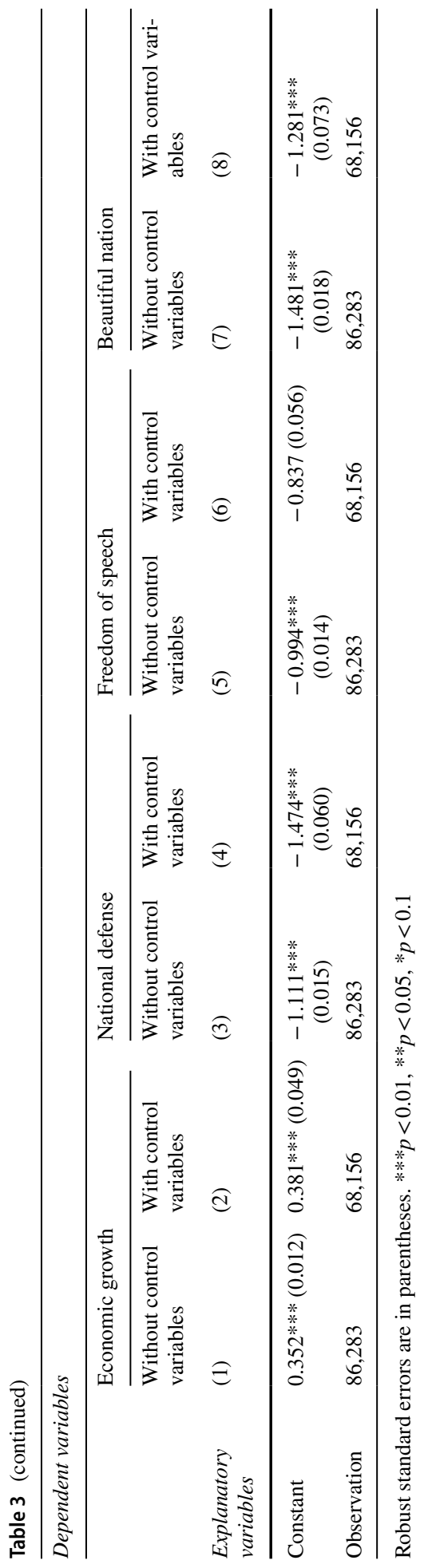


financial satisfaction. As Welzel and Inglehart (2010) indicate, postmaterialist needs are rooted in the human motivational system.

Regarding the control variables, the regression results show that people with lower education and income and those with full-time employment and non-government jobs are more interested in the economic growth of their countries. People from less populated areas and less religious backgrounds are more pro-economic growth too (column 2 of ). We also find that a stronger national defense preference is higher among older, married, nationalistic, and educated individuals. Higher-income earners and government employees tend towards national defense (column 4 of Table 3).

As can been seen in column 6 of Table 3, younger, not married, and more religious respondents and those who live in larger urban areas support freedom of speech more than other respondents. Finally, the preference for having a beautiful nation is less profound among respondents from older, more religious, and higher-income earner groups. People with higher confidence in government also demonstrate less interest in this national priority (column 8 of Table 3).

We perform two series of robustness checks to confirm the validity of our main results, which are explained in the following sections.

\subsection{Issue of Endogeneity}

As a robustness check, we re-estimate Eq. 1 using the Probit model with endogenous regressors. The reason for utilizing this approach is to account for endogeneity in the model due to the possible simultaneity issue (e.g., bidirectional relationships between financial satisfaction and an individual's preference). For example, we assume that financial satisfaction may shape an individual's preference; however, one may argue that changes in public policy can lead to changes in financial satisfaction through, for example, influencing households' financial situations.

We use life satisfaction, income scale, age, gender, and higher education as instruments for financial satisfaction in the estimations. Previous studies have shown that these variables are important determinants of individuals' financial satisfaction. For example, Fan and Babiarz (2019) look at the moderating roles of gender and marital status on associations between demographic, socioeconomic, behavioral variables and financial satisfaction. They report that married men and women are more financially satisfied than their divorced counterparts. However, married men fell behind their widowed counterparts in terms of financial satisfaction. Plagnol (2011) considers the role of assets and liabilities and income on financial satisfaction at different stages of a life cycle. She provides evidence that increasing financial satisfaction at older ages is partially related to increases in financial assets, reduced liabilities, and dependency burden at this life stage.

The results of the Probit model with endogenous regressors are presented in Table 4. The coefficients for national priorities of economic growth and freedom of speech are still statistically significant and maintain their expected negative and positive signs, respectively (columns 1 and 3 of Table 4). In addition, the result shows that the link between financial satisfaction and national defense is statistically insignificant (column 2 of Table 4). In general, these results reaffirm our earlier findings obtained from the Probit regressions. 
Table 4 Probit model with endogenous regressors

\begin{tabular}{lllll}
\hline $\begin{array}{l}\text { Dependent variables } \\
\text { Economic growth }\end{array}$ & National defense & Freedom of speech & Beautiful nation \\
\hline Explanatory variable & $(1)$ & $(2)$ & $(3)$ & $(4)$ \\
\hline Financial satisfaction & $-0.054^{* *}(0.016)$ & $0.030(0.022)$ & $0.036^{* *}(0.018)$ & $0.038(0.025)$ \\
Constant & $0.614(0.093)$ & $-1.271^{* * *(0.126)}$ & $-1.146^{* * *}(0.107)$ & $-1.691(0.143)$ \\
Observation & 86,282 & 86,282 & 86,282 & 86,282 \\
\hline
\end{tabular}

Robust standard errors are in parentheses. $* * * p<0.01$ and $* * p<0.05$

\subsection{Country-level Analysis}

In addition to individual-level analyses, we estimate the association between financial satisfaction and preferences for various national priorities using the aggregate data at the country level. In doing so, we take the average score of financial satisfaction for each country in the WVS6. For example, the mean values for the measure of financial satisfaction (ranging from 1 to 10) for Australia and India were 6.32 and 5.94, respectively. Table 6in Appendix shows the mean value of financial satisfaction for sample countries. As dependent variables, we use the percentage of total respondents who chose one of the four national priorities. For example, 67.2, 16.4, 12.5 and $3.9 \%$ of Malaysian respondents in WVS6 chose "A high level of economic growth", "Making sure this country has strong defense forces", "Seeing that people have more say about how things are done at their jobs and in their communities" and "Trying to make our cities and countryside more beautiful" as the first aim of the country.

The results of this robustness check are presented in Table 5. We apply both OLS and 2SLS estimators. For the 2SLS estimation, the average of gross domestic product (GDP) (converted by purchasing power parity (PPP) conversion factor) per capita (GDPC) from 2010 to 2014 and average of Human Development Index (HDI) for the period of 2010-2014 are used as instruments for financial satisfaction when we include preference of economic growth, national defense and beautiful nation as the dependent variables. Data for GDPC and HDI are obtained from the World Development Indicators database of the World Bank (2021) and the United Nations (2021), respectively. We use the average value of GDPC and HDI from 2010 to 2014 because the WVS6 was conducted over this period across sample countries. For freedom of speech as a dependent variable, we use the average of GDPC from 2010 to 2014 and the 2014 financial literacy score of countries (Klapper et al., 2015) as instruments. The reason for using different instruments for financial satisfaction in the freedom of speech modeling is that when we include GDPC and HDI as instruments, they do not pass the test of endogeneity.

The results of country-level regressions are reported in Table 5. In line with our individual-level analyses in Tables 3 and 4, the association between financial satisfaction and preference of economic growth is negative and significant in both OLS and 2SLS estimations (columns 1 and 2 of Table 5). When freedom of speech is the dependent variable, financial satisfaction has a positive and significant association with this 


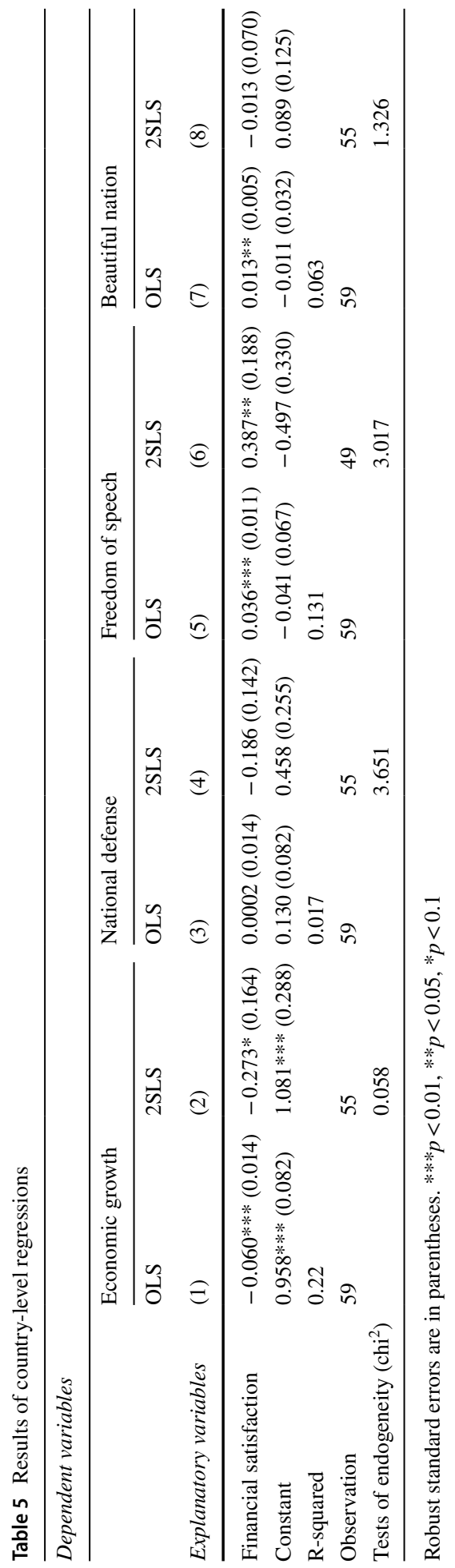



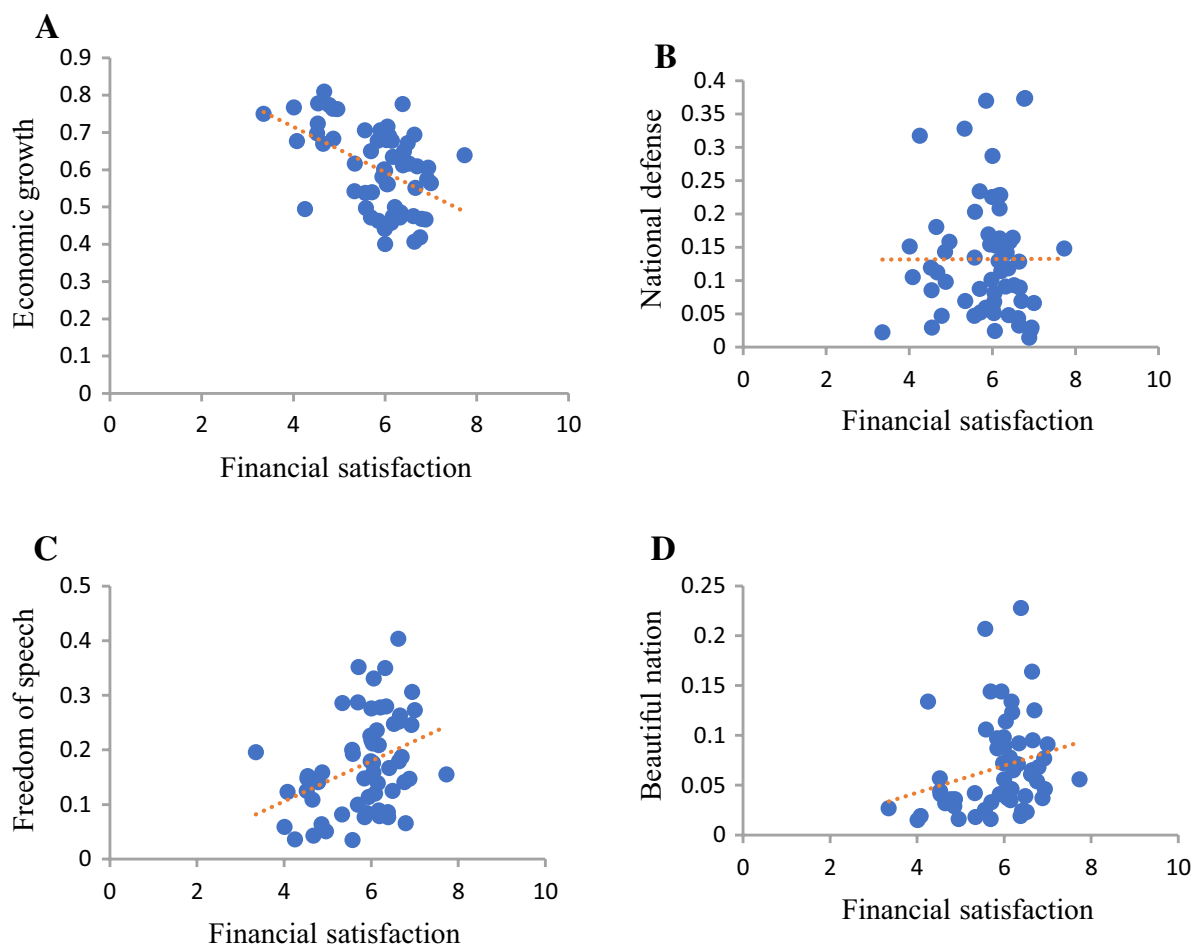

Fig. 1 The association between financial satisfaction and four different national preferences. Source: WVS6. Note: $\mathrm{X}$-axis is the mean value of financial satisfaction (ranging from 1 to 10) for the sample countries. Y-axis is the percentage of total respondents in the sample countries who chose a particular national priority

priority (columns 5 and 6 of Table 5). Figure 1 shows the scatter plots of financial satisfaction and four different national priorities. The negative and positive slope of the trend lines in panels A and C of Fig. 1 graphically support our regression results. Finally, the findings of OLS and 2SLS estimations do not show consistent coefficients of financial satisfaction in terms of signs and significance for "National defense" and "Beautiful nation."

These results support the Inglehart $(1971,1997)$ theories of value change and modernization. When societies progress with economic development and address material concerns at a national level, individuals shift their attention to postmaterialist values such as self-expression values, quality of life and free choice. 


\section{Conclusion}

A growing body of literature investigates the role of financial satisfaction in shaping individuals' decisions and behavior. Using a large sample across countries, we extend this literature by demonstrating an association between financial satisfaction and preferences for national priorities. Using cross-sectional data and applying static Probit model, we find that individuals with higher levels of financial satisfaction tend to prefer postmaterialist values, such as demonstrating their willingness to expand freedom of speech and improving the beauty in their home country (or supporting environmental friendly policies) over the materialistic values of economic growth. Our findings are robust after applying different estimation methods and using different samples.

The results are consistent with the theories of the hierarchy of needs and value change and expand our understanding of financial satisfaction implications in future policy planning of nations. Economists and policymakers may benefit from this knowledge to promote projects aligned with the public opinions of the majority of residents (e.g. projects related to green infrastructure or press freedom in countries where the greater population enjoys a higher level of financial satisfaction). This can potentially reduce the likelihood of agency dilemma in democratic political systems.

Future researchers can use public opinion surveys at regional levels and expand the findings of this study by evaluating the role of financial satisfaction as a determinant of other political and economic national preferences (e.g., fighting rising prices of goods and services). Future studies may also examine the bi-directional relationship between financial satisfaction and individuals' national preferences using time-series analyses if the annual data become available over time.

\section{Appendix}

See Table 6. 
Table 6 Mean values of financial satisfaction (ranging from 1 to

\begin{tabular}{|c|c|c|c|}
\hline Country & Mean & Country & Mean \\
\hline Algeria & 5.99 & Netherlands & 6.92 \\
\hline Argentina & 6.52 & New Zealand & 6.88 \\
\hline Armenia & 4.25 & Nigeria & 5.69 \\
\hline Australia & 6.32 & Pakistan & 6.76 \\
\hline Azerbaijan & 5.58 & Palestine & 4.65 \\
\hline Belarus & 4.78 & Peru & 6.03 \\
\hline Brazil & 6.21 & Philippines & 6.34 \\
\hline Chile & 6.00 & Poland & 5.71 \\
\hline China & 6.19 & Qatar & 7.73 \\
\hline Colombia & 6.70 & Romania & 5.84 \\
\hline Cyprus & 5.90 & Russia & 4.87 \\
\hline Ecuador & 6.66 & Rwanda & 6.09 \\
\hline Egypt & 4.86 & Singapore & 6.41 \\
\hline Estonia & 5.34 & Slovenia & 6.06 \\
\hline Georgia & 4.01 & South Africa & 6.13 \\
\hline Germany & 6.62 & South Korea & 5.69 \\
\hline Ghana & 4.52 & Spain & 5.56 \\
\hline Haiti & 3.35 & Sweden & 6.94 \\
\hline Hong Kong & 6.64 & Taiwan & 6.39 \\
\hline India & 5.94 & Thailand & 6.17 \\
\hline Iraq & 5.85 & Trinidad & 5.98 \\
\hline Japan & 6.04 & Tunisia & 4.96 \\
\hline Jordan & 5.33 & Turkey & 6.17 \\
\hline Kazakhstan & 6.05 & Ukraine & 4.54 \\
\hline Kyrgyzstan & 6.38 & United States & 6.15 \\
\hline Lebanon & 6.00 & Uruguay & 6.64 \\
\hline Libya & 6.79 & Uzbekistan & 4.08 \\
\hline Malaysia & 6.49 & Yemen & 4.67 \\
\hline Mexico & 7.00 & Zimbabwe & 4.53 \\
\hline Morocco & 5.57 & & \\
\hline
\end{tabular}

Source: WVS6

Funding The authors received no financial support for the research, authorship, and/or publication of this article.

Availability of Data and Material Data will be available upon request.

\section{Declarations}

Conflicts of Interest The authors declare that they have no conflicts of interest.

Ethical Approval This article does not contain any studies with human participants or animals performed by any of the authors. 


\section{References}

Alesina, A., \& Fuchs-Schündeln, N. (2007). Good-Bye Lenin (or Not?): The effect of communism on people's preferences. The American Economic Review, 97, 1507-1528.

Archuleta, K. L., Britt, S. L., Tonn, T. J., \& Grable, J. E. (2011). Financial satisfaction and financial stressors in marital satisfaction. Psychological Reports, 108(2), 563-576.

Beamer, G. D. (2010). Creative politics: Taxes and public goods in a federal system. University of Michigan Press.

Bennulf, M., \& Holmberg, S. (1990). The green breakthrough in Sweden. Scandinavian Political Studies, 13(2), 165-184.

Boyle, J. (2012). Shared money, less conflict, stronger marriages: the relationship between money ownership perceptions, negative communication, financial satisfaction, marital satisfaction and marital instability. In: PhD Dissertation, Kansas State University.

Brown, S., Durand, R. B., Harris, M. N., \& Weterings, T. (2014). Modelling financial satisfaction across life stages: A latent class approach. Journal of Economic Psychology, 45, 117-127.

Chong, S. C., Lim, C. S., \& Wong, H. C. (2014). Financial satisfaction, resource transfers and bequest motives among Malaysia's urban older adults. Australian Journal of Basic and Applied Sciences, 8(8), $15-33$.

Davis, O. A., Hinich, M. J., \& Ordeshook, P. C. (1970). An expository development of a mathematical model of the electoral process. The American Political Science Review, 64(2), 426-448.

Facchini, F., \& Melki, M. (2019). Egalitarianism and the democratic deconsolidation: Is democracy compatible with socialism? Public Choice. https://doi.org/10.1007/s11127-019-00744-X

Fan, L., \& Babiarz, P. (2019). The Determinants of Subjective Financial Satisfaction and the Moderating Roles of Gender and Marital Status. Family and Consumer Sciences Research Journal, 47(3), 237-259.

Farzanegan, M. R., \& Gholipour, H. G. (2021). Growing up in the Iran-Iraq War and Preferences for Strong Defense. Review of Development Economics. https://doi.org/10.1111/rode.12806.

Gerrans, P., Speelman, C., \& Campitelli, G. (2014). The relationship between personal financial wellness and financial well-being: A structural equation modelling approach. Journal of Family and Economic Issues, 35(2), 145-160.

Giuliano, P., \& Spilimbergo, A. (2014). Growing up in a recession. Review of Economic Studies, 81, $787-817$.

Grable, J. E., Britt, S., \& Cantrell, J. (2007). An exploratory study of the role financial satisfaction has on the thought of subsequent divorce. Family and Consumer Sciences Research Journal, 36(2), 130-150.

Heinemann, F. (2008). Is the welfare state self-destructive? A study of government benefit morale. Kyklos, 61(2), 237-257.

Inglehart, R. (1971). The silent revolution in Europe: Intergenerational change in post-industrial societies. American Political Science Review, 65(4), 991-1017.

Inglehart, R. (1997). Modernization and postmodernization: Cultural, economic, and political change in 43 societies. University of Michigan Press.

Inglehart, R., \& Flanagan, S. C. (1987). Value change in industrial societies. American Political Science Review, 81(4), 1289-1319.

Inglehart, R., \& Abramson, P. R. (1994). Economic security and value change. American Political Science Review, 88(2), 336-354.

Inglehart, R., \& Welzel, C. (2005). Modernization, cultural change, and democracy: The human development sequence. Cambridge University Press.

Inglehart, R., C., Haerpfer, A., Moreno, C., Welzel, K., Kizilova, J., Diez-Medrano, M., Lagos, P., Norris, E., Ponarin, E., Puranen, B., et al. (Eds.). (2014). World Values Survey: Round Six - Country-Pooled Datafile Version. http://www.worldvaluessurvey.org/WVSDocumentationWV6.jsp. Madrid: JD Systems Institute.

Klapper, L., Lusardi, A., \& van Oudheusden, P. (2015). Financial Literacy Around the World: Insights from the Standard \& Poor's Rating Services Global Financial Literacy Survey. https://gflec.org/wp-content/ uploads/2015/11/Finlit_paper_16_F2_singles.pdf

Maseland, R., \& Hoorn, A. (2011). Why Muslims like democracy yet have so little of it. Public Choice, 147, 481-496.

Maslow, A. H. (1943). A theory of human motivation. Psychological Review, 50(4), 370-396.

Maslow, A. H. (1954). Motivation and personality. New Delhi: Prabhat Prakashan.

Maslow, A. H. (1970). Motivation and personality. New Delhi: Prabhat Prakashan. 
Ng, W., \& Diener, E. (2014). What matters to the rich and the poor? Subjective well-being, financial satisfaction, and postmaterialist needs across the world. Journal of Personality and Psychology, 107(2), 326-338.

Page, B. I., \& Shapiro, R. Y. (1983). Effects of public opinion on policy. The American Political Science Review, 77(1), 175-190.

Plagnol, A. C. (2011). Financial satisfaction over the life course: The influence of assets and liabilities. Journal of Economic Psychology, 32(1), 45-64.

Prawitz, A., Garman, E. T., Sorhaindo, B., O’Neill, B., Kim, J., \& Drentea, P. (2006). Incharge financial distress/financial well-being scale: Development, administration, and score interpretation. Journal of Financial Counseling and Planning, 17(1), 34-50.

Rautio, N., Kautiainen, H., Koponen, H., Mantyselka, P., Timonen, M., Niskanen, L., et al. (2012). Financial satisfaction and its relationship to depressive symptoms in middle-aged and older adults: Results from the FIN-D2D survey. International Journal of Social Psychiatry, 59, 239-246.

Sen, A. (2018). Collective choice and social welfare. Harvard University Press.

Spaiser, V., Ranganathan, S., Mann, R. P., \& Sumpter, D. J. (2014). The dynamics of democracy, development and cultural values. PLOS ONE, 9(6), 1-11.

Stack, S., \& Cao, L. (1997). The effect of financial satisfaction on female suicide attitudes in China. Omega, 36(2), 161-167.

Tharp, D. T., Seay, M. C., Carswell, A. T., \& MacDonald, M. (2020). Big five personality traits, dispositional affect, and financial satisfaction among older adults. Personality and Individual Differences, 166,110211

Tomz, M., Weeks, J. L., \& Yarhi-Milo, K. (2020). Public opinion and decisions about military force in democracies. International Organization, 74(1), 119-143.

United Nations. (2021). Human development index (HDI). Available at: http://hdr.undp.org/en/content/ human-development-index-hdi

Welzel, C., \& Inglehart, R. (2010). Agency, values, and well-being: A human development model. Social Indicators Research, 97(1), 43-63.

West, T., \& Cull, M. (2020). Future expectations and financial satisfaction. Economic Papers. https://doi. org/10.1111/1759-3441.12292

World Bank. (2021). GDP per capita, PPP (constant 2017 international \$). Available at: https://data.world bank.org/indicator/NY.GDP.PCAP.PP.KD

Xiao, J. J., Chen, C., \& Chen, F. (2014). Consumer financial capability and financial satisfaction. Social Indicators Research, 118(1), 415-432.

Publisher's Note Springer Nature remains neutral with regard to jurisdictional claims in published maps and institutional affiliations. 